DOI : $10.14746 / p p .2014 .19 .4 .8$

Jeroen Van den $\mathrm{BOSCH}$

Poznan

\title{
Mapping Political Regime Typologies
}

\begin{abstract}
The research field of regime theory has seen a proliferation of different approaches and typologies to explain the ever-changing reality. This paper has created a typology of these regime typologies and their respective datasets in order to describe and analyze their various merits for research. Finally this paper maps various typologies according to their most common research areas. The aim is to maximize the application potential each of specific typology, highlight their limits and aid scholars in their selection of typologies for qualitative or quantitative research in order to get a better understanding of democratization processes or regime theories.
\end{abstract}

Key words: political regimes, typologies, measures of democratization, methodology

W hile most researchers have been focusing on democracy and democratization, one cannot forget that many parts of the word and a huge chunk of the global population still live under authoritarian rule. One should bear in mind that the in-depth research on other regimes started surprisingly late for the discipline of comparative politics. The works of Hannah Arendt on totalitarianism, Robert Dahl's Polyarchy and Juan Linz's typology to separate democracies from non-democracies were very influential contributions in the 1960-1970s. As the third wave of democracy in the 1990s seemed to reach global proportions and succeed to diffuse the practice of elections as the only recognized form of legitimization around the world, researchers' susceptibility for the phenomenon of 'elections without democracy' resulted in the ground-breaking work of Steven Levitsky and Lucan Way to once more, break open the dichotomous approach toward political regimes and voice the need of clear concepts and typologies for further analysis.

Their echo did not go unheard: In response to the growing amount of authoritarian regimes with a democratic façade (once labeled as 'democracies with adjectives' by Levitsky and Way), scholars developed new classifications and typologies in the second half of the 1990s. And, in addition, they built up enormous datasets of countries with various time frames and different scopes with the aim to apply and test their new typologies.

This paper will portrait a typology of existing typologies and briefly discuss some recent examples of them from the literature. Its aim is to analyze the merits and limitations for the study and classification of authoritarian regimes, and hopefully aid scholars in their selection of typologies for qualitative or quantitative research in order to get a better understanding of democratization processes or regime theories. 


\section{A typology of regime typologies}

In order to analyze political regimes in general and autocratic ones in particular, it would be frowned upon if the author did not provide a (workable) definition of what constitutes a 'political regime'. For this purpose, this paper relies heavily on the work of S. Skaaning, who identified four defining properties of different regime types. By comparing ten definitions of regimes, Skaaning points out that any definition of political regimes should encompass the group's access to political power, the way they structure the interaction in the political power center (horizontal relation: the relationship between the executive, legislative and judicative powers) and its relations with the broader society (vertical relation: method of access to the principal political posts). Finally, the fourth element is the character of the ruler(s), which allows us to differentiate between autocratic and democratic regimes and their behavior (Skaaning, 2006, p. 13-14; Van den Bosch, 2013).

Skaaning de facto created a meta-definition of a political regime. By detangling the existing conceptual origins of existing definitions, he provides a framework in which all these definitions can be redefined in order to check their accuracy. Even today, scholars do not use one definition and as every typology is created according to their own definition, Skaaning's meta-approach allows us to compare various regime typologies.

Summarizing Skaaning, a definition of regimes should sound as follows: A political regime designates the institutionalized set of fundamental formal and informal rules identifying the political power holders (character of the possessor(s) of ultimate decisional sovereignty) and it also regulates the appointments to the main political posts (extension and character of political rights) as well as the vertical limitations (extension and character of civil liberties) and horizontal limitations on the exercise of political power (extension and character of division of powers - control and autonomy) (Skaaning, 2006, p. 15).

Regime typologies then should (ideally) be able to divide different types so they may reach beyond a clear and parsimonious description of their characteristics to classify cases (Elman, 2005). They should identify and order typical characteristics of regimes in such a way that differences and shifts on the four defining treats identified by Skaaning ((in)formal rules, attribution of main political posts, vertical and horizontal limitations) can be observed and are meaningful in explaining regime behavior. Only then can hypotheses and theories based on these typologies be tried and tested.

Table 1. shows two broad different approaches for measuring regime types (families), with subtypes for categorical typologies (levels). The most commonly used studies have been added as examples. The first question of this research paper is then: If all typologies have a different focus, how does one know for what studies a typology can be used beyond the research of their initial conception? As Cheibub et al. already pointed out:

"We believe that existing measures of political regimes are significantly different in ter$\mathrm{ms}$ of both their theoretical grounding and operationalization and, for this reason, should not be treated as interchangeable. [...] In our view, we should take the differences across measures more seriously and evaluate them in terms of whether they (1) serve to address important research questions, (2) can be interpreted meaningfully, and (3) are reproducible" (Cheibub, Ghandi, 2009, p. 2). 
A typology of typologies of authoritarian regimes

\begin{tabular}{||l|l|l|l||}
\hline \multicolumn{1}{|c|}{ CONTINUOUS } & \multicolumn{1}{c|}{ Dichotomous } & \multicolumn{1}{c|}{$\begin{array}{c}\text { CATEGORICAL } \\
\text { Trichotomous }\end{array}$} & \multicolumn{1}{c||}{ Polychotomous } \\
\hline Cutright (1963) & Sartori (1987) & Gasiorowski (1996) & Linz \& Stepan (1996) \\
\hline Freedom House (2010) & Alvarez et al. (1996) & Mainwaring et al. (2007) & Hadenius \& Teorell (2010) \\
\hline Polity (2010) & Boix et al. (2012) & Schedler (2010) & Geddes et al. (2013) \\
\hline & Cheibub et al. (2010) & Levitsky \& Way (2010) & Kailitz 2013 \\
\hline
\end{tabular}

In order to answer this question, the author presents a typology of regime typologies. The aim of this paper is to present the reader with the merits of each typology and highlight their limits by stating some pitfalls for which these different classifications should not be used. The purpose of this is not to criticize the authors of these typologies, nor to select a favorite one that should be used for all kinds of research. This paper aims to make some recommendations on what typologies to choose for which research by mapping them amongst the most common research fields linked with democratization.

The examples of different types that are listed in table 1. are not comprehensive or complete. They have been chosen according to their reputation (recurrence and widespread use) within the literature and time of publication. All the examples are illustrative for the given sort of typology and a closer analysis of them will help to understand the merits and limitations of each family as a whole and its respective levels in particular. This paper will briefly describe two representative examples of each type (marked in bold in the table 1.) in order to clarify the explanatory potential of each sort typology and will summarize its findings in the conclusion.

The first family are those typologies that use a continuous measure of 'democraticness'. The second kind encompasses regime types that have been defined according to certain categories. The number of analytical categories explains the variation in levels. What is important here is that these 'family-subtypes' do not only formally differ according to a degree (the number of categories), but that they inherently possess different characteristics, focal points and potentials.

\section{Continuous measures}

This article will start with those typologies that use a continuous measure of democracy. The two most famous examples are listed: Freedom House (FH) is an organization that classifies all independent countries according to the twin dimension of civil and political rights. Every country is listed on a scale from 1 to 7, with 1 being absolutely free and 7 absolutely not free. Later the scale was divided into three sectors: free (1-2.5), partly free (3-5) and not free (5.5-7).

Polity then has a similar purpose in measuring democracy, although a different scale (from -10 (absolutely authoritarian) to +10 (completely democratic)). As countries are placed on this scale and switch between regimes with arbitrarily cut-off points: autocra- 
cies $(-10$ to -7$)$, "incoherent polities" or "anocracies" $(-6$ to +6$),{ }^{1}$ and democracies $(+7$ to $+10)$; there are some serious doubts as to which level these 'classifications' can and should be used to create regime typologies.

Also, in the case of typologies that cover authoritarian regimes, the use of arbitrary thresholds to distinguish between regimes is a very dangerous thing: These typologies have been criticized in the literature because it is generally impossible to interpret a country's movement across a particular cut-off point in a substantive way (Boix, Miller, 2012, p. 6). M. Boogaards takes a firm stance when quoting K. Bollen \& R. Jackman and G. Sartori: "If one takes the notion that "democracy is always a matter of degree" to its logical extreme, then "it is meaningless to claim that democracy was inaugurated in a given country on a single date' [...]. Scholars who conceive of democracy as a matter of degree treat democracy and its absence as endpoints of a continuum, on which any thresholds or boundaries are arbitrary. Such 'degreeism' [...] not only does away with the notion of a democratic transition, but it also negates the concept of regime and regime type."”

Regarding FH, Cheibub et al. highlight its non-transparent and arbitrary aggregation rules. They argue that $\mathrm{FH}$ is in essence not a continuous scale or an ordinal ranking, but at best a categorical variable, where its various categories can be arrived at through billions of possible combinations (Cheibub, Ghandi, 2009, p. 9). Polity, on the other hand, is transparent and provides its coding criteria. Gleditsch and Ward argue that its data are in essence categorical, but that the categories are not precise. The biggest criticism on both datasets is that they do not give valid arguments on their choice of coding rules (FH do not even provide them at all!), that the weight attributed to this or that rule is completely arbitrary (though Polity made efforts to improve their reliability over the years) and finally that they code criteria, whose measurement has nothing to do with the concept of democracy. For instance, Polity codes 'the absence of political violence' as an important factor of democratization, while this characteristic is alien to almost all definitions of democracy (Cheibub, Ghandi, 2009, p. 9-11).

Of course, this critique does not render these 'measures of democracy' useless for comparative politics. On the contrary, both measurements (and the extensive datasets that accompany them) are amongst the most used in the literature. Their strength lies in the fact that they measure 'democraticness', ${ }^{3}$ that is: they are able to capture to which degree

${ }^{1}$ The concept of anocracy uses weakness and instability as specific, defining characteristics. For the author this is not enough to classify anocracy as a separate regime. If we compare its qualities with the definition of a political regime there are not enough definitive treats to classify it separately. When a democratic regime loses its capability to accommodate conflicts, is unable to prevent violent outbreaks and is pressured to give in to unelected parties it is not an anocracy, but a 'weak democracy', unable to uphold neither civil rights nor the rule of law. In the other direction, when an autocracy is no longer able to maintain its dominant position and must share power with other parties we call this a 'weak autocracy' (Van den Bosch, 2013).

${ }^{2}$ See: K. Bollen, R. Jackman, Democracy, stability, and dichotomies, "American Sociological Review" 1989, vol. 54, no. 4, p. 615 and G. Sartori, Comparing and miscomparing, "Journal of Theoretical Politics" 1991, vol. 3. Quote from Boogaards, 2010, p. 476.

${ }^{3}$ Cheibub et al. however question to what degree FH (and Polity) can correctly estimate some of its coding criteria, claiming that from their personal experience the data they require are hard, if not impossible, to obtain (see: Cheibub, Ghandi, 2009, p. 11). 
countries or regimes are shifting on the horizontal and vertical axes, as part of the definition of democracy, created by Skaaning. By checking the relation, the checks and balances between legislative, executive and the judiciary branch; and the levels of freedom (that is political and civic rights) that the people living under a certain regime enjoy, these measurements give one measurement for all regimes. As stated above, this measurement might put too much weight on some variables and ignore others, it might contain mistakes in its coding, but it still is a measure, which is repeated for almost all countries. In defense of the quality of FH and other continuous measures, A. Schedler once wrote: "In its assessments of political rights, Freedom House asks more questions than we need, yet still asks the right questions, in order to judge the democratic quality of electoral processes." (Schedler, 2006, p. 10) Despite their methodological opaque and disputed coding criteria, their output has been reliable, and the position of countries on their scale has been accepted by most authors.

These datasets have been proven enormously helpful to assess the (un-)democratic level of different countries; especially over large time spans. This makes it possible to map their trajectory ${ }^{4}$ toward or away from democracy. They also can assess if regimes have been backsliding or improving their human rights record and in which time frame. Nonetheless, users of these datasets must realize that their 'degree of democracy' does not capture fundamental qualitative differences between political regimes apparently exhibiting the same degree of democratization (Kailitz, 2013, p. 39). Also, if one believes that democracy can be measured over all regimes, one has to be prepared to argue that even dictatorships inhibit (low but) positive levels of democracy (Cheibub, Ghandi, 2009 , p. 12). Howerver, such measurements make explanatory qualitative analysis very difficult, if not impossible, and creating seemingly categorical classifications based on these democratic scales is a pitfall to be avoided at all cost.

A regime typology, which uses categorical definitions to compound concepts that are structured as types along one or more dimensions, has the potential to go beyond description or classification and does enable some qualitative explanations about regime behavior. Therefore, this kind of typology can be used for testing theories and hypotheses. This paper will argue that categorizing these various typologies in their 'own' typology is not the result of some arbitrary formal differences between types, but has been done according to their choice of level of analysis and the impact of such decisions on comparative research.

\section{Dichotomous measures}

While all the four sorts of typologies contribute to similar research fields, they focus on different defining characteristics of Skaaning's interpretation of political regimes, and in the end they aim to explain disparate phenomena. Among categorical typologies, the dichotomous ones have been developed over time as the most robust and reliable classifi-

\footnotetext{
${ }^{4}$ The author especially uses the concept 'trajectory' instead of 'road' or 'path' as these conceptions are all more semantically loaded with a certain teleology. In this case 'trajectory' leaves (by association) more room for detours, setbacks and obstacles than the latter.
} 
cations. Although one has to take into account that the mechanization of coding rules has only been possible by stripping the complicated concept of democracy to its bare essence. In result, these typologies all end up using a minimalistic definition of democracy.

One of the first questions that arise in the context of comparing dichotomous typologies is to what degree they differ? They only classify regimes in autocracies or democracies. So their datasets may vary in scope and range (number of countries and years covered), but the basic definition of which is what should be nearly identical for these classifications. In answer Boix, Miller \& Rosato firmly state:

"Political scientists have devised dozens of distinct measures of democracy and theorized in dozens of other articles on the proper measurement of democracy and the shortcomings of existing approaches. Furthermore, the differences are not merely academic. Empirical results can depend on the specific measure of democracy used [...] and the period covered [...].” (Boix, Miller, 2012, p. 4)

Despite the fact that these typologies (almost) all use a minimalistic definition of democracy, their results differ considerably because they adapt their definition (and in consequence, coding rules) to their research design (especially their scope and range). The issue becomes very clear if one compares the typologies (and datasets) of Boix et al. with Cheibub et al. Both examples are arbitrarily picked, although both works are recent and known.

Cheibub et al. analyze democratic regimes in the tradition of M. Alvarez and A. Przeworski. Their definition sounds as follows:

"Democracies are regimes in which governmental offices are filled as a consequence of contested elections. This definition has two main parts: 'offices' and 'contestation'. For a regime to be democratic, both the chief executive office and the legislative body must be filled by elections. Contestation occurs when there exists an opposition that has some chance of winning office as a consequence of elections." (Cheibub, Ghandi, 2009, p. 3)

Based on the work of Przeworski, the element of electoral contestation is defined by ex ante uncertainty, ex post irreversibility (the results cannot be undone after the election), and repeatability, which means that such elections are held at recurring and known intervals. To be classified as a democracy, a political regime must meet all the following four requirements: (1) The chief executive must be chosen by popular election or by a body that was itself popularly elected. (2) The legislature must be popularly elected. (3) There must be more than one party competing in the elections. (4) An alternation in power under electoral rules identical to the ones that brought the incumbent to office must have taken place (Cheibub, Ghandi, 2009, p. 3).

The weak link in the chain of this coding system is the repeatability of the elections process. What about leaders that come to power through democratic elections, but afterwards become more authoritarian? Or another issue: What if a party is so popular and becomes reelected over and over again, directly challenging the criterion of repeatability? Cheibub et al. admit that the "implementation of the last rule is more complicated since it requires that we make one assumption and one decision about what kind of error we are willing to accept." (Cheibub, Ghandi, 2009, p. 4). Of course, they monitor these cases, but as some of them are observationally equivalent, their classification remains impossible without introducing subjectivity into the coding process. To successfully classify cases, they will have to bide their time and wait for an alternation in future elections. The bias is 
greatest in post-Soviet states, where the ruling party has stayed in power despite the introduction of regular elections (Cheibub, Ghandi, 2009).

In defense of their minimal definition, Cheibub et al. state that: "(O)ne should consider the primary purpose for the categorization of political regimes: the conduct of empirical research. In this regard, a measure of democracy based on a minimalist conception, is compatible with most of the theoretical issues that animate empirical research on political regimes." And: "If democracy requires civil liberties, political rights, freedom of the press, and other freedoms, then inquiries about the connection between democracy and such freedoms are also precluded." (Cheibub, Ghandi, 2009, p. 6-7).

The argument that the more elements included in a definition of democracy, the greater the difficulties for coding datasets and the less applicable or robust a typology becomes, is a valid one and should not be disregarded. The geographic scale and time frame of the datasets created through these dichotomous typologies are impressive, going back to centuries with almost a global reach. It is a pity that a minimalistic definition precludes (some) error, but in exchange offers the most extensive datasets, with the most robustly empirically tested criteria.

Of course, even within the dichotomous sort differences remain: If one compares Cheibub et al. with C. Boix, M. Miller and S. Rosato's typology, one sees that even the slightest alternation in the minimum definition can have remarkable differences. Boix et al. encompass all four (see above) characteristics of Cheibub et al. in two main rules. What they classify under contestation are: (1) The executive is directly or indirectly elected in popular elections and is responsible either directly to voters or to a legislature. (2) The legislature (or the executive if elected directly) is chosen in free and fair elections (Boix, Miller, 2012, p. 8).

In their coding, they likewise use the concept of electoral turnover, based on the works of Przeworski. Only, they developed a mechanism to overcome the problem of Cheibub et al., namely their 'human' intervention in the coding criteria to classify dubious cases: By checking "the history of those cases with no electoral turnover for a sufficiently long period of time (over two electoral terms) to examine whether internal coups, external interventions, abuses of state power, or reports of fraud could explain the prolonged control of the executive by the same party. If there were none and we observed contested elections, we coded the period as having free and fair elections. If a peaceful governmental turnover was observed, we applied the same check to determine how far back in time the condition of free and fair elections applied." (Boix, Miller, 2012, p. 9)

The slight alteration to the minimal definition however is their choice of adding the rule that 'a majority of adult men has the right to vote.' By including coding for suffrage, they involve a new, easily verifiable rule that does cause a landslide in their empirical results compared to other typologies, which ignore this dimension. The difference is most noticeable for observations prior to World War II. The authors admit that opting for (implemented) male suffrage and not the universal right to vote is an arbitrary choice and serves to avoid loss of information (especially for observations during the first wave of democratization). In their defense they do state that the rule of male suffrage is a flexible threshold, which can be altered by other scholars to fit their research (Boix, Miller, 2012, p. 10-11).

A dichotomous approach, however robust it may be, still conceals at lot of information. What about authoritarian regimes that democratize over time? Should the basic 
cut-off point that divides regimes always be free elections? The impressive datasets, which accompany these typologies, might be crucial to take on historical research to expose correlations with structural factors (and how these have changed over time in relation to democracy), but these typologies remain completely blind to any variations between different authoritarian regimes, and therefore cannot be used to study them in depth.

Such typologies, however, serve to break open the black box of the state in order to identify and explain differences in policy and performance among states: to check the differences in long-term economic performance, analyze the distribution of public goods, the link between regime behavior and international trading norms, variation in foreign policy, to compare states on their entry into and performance in war, to explain differences in equality between societies, etc. The extensive datasets then, make robust hypotheses possible. However, these dichotomous measures do not go beyond the first dimension identified by Skaaning, which is the 'character' of the regime.

\section{Trichotomous measures}

As mentioned in the introduction, the end of the Cold War blew a new wind through regime theories. The work of S. Levitsky \& L. Way $(\mathrm{L} \& \mathrm{~W})$ as the basis for this specific kind of typology has also been indispensible. L\&W aimed to create conceptual clarification among the 'democracies with adjectives' that is, the terminology to describe failed or incomplete transitions to democracy during the third wave. They were the first to identify and work out an innovative new typology that could capture this new reality. Authoritarian regimes with elections did exist before the Cold War of course, but were very few in number and therefore often overlooked or misclassified. After 1989 these regimes proliferated on a global scale.

Trichotomous typologies consider a certain regime type that possesses characteristics of both democracies and autocracies as a separate type: a hybrid regime. L\&W added a new defining characteristic to distinguish between democracies and those authoritarian regimes that imitate the former by allowing free, fair and competitive elections; full adult suffrage; providing the broad protection of civil liberties, including freedom of speech and association; and do not possess interfering 'tutelary' bodies (Levitksy, Way, 2010, p. 6). In order to filter out the democratic façades, the authors added the category of 'a level playing field':

"Obviously, a degree of incumbent advantage - in the form of patronage jobs, pork-barrel spending, clientelist social policies, and privileged access to media and finance - exists in all democracies. In democracies, however, these advantages do not seriously undermine the opposition's capacity to compete. When incumbent manipulation of state institutions and resources is so excessive and on-sided that it seriously limits political competition, it is incompatible with democracy." (Levitksy, Way, 2010, p. 6)

Without the addition of this fifth category, these hybrid regimes would not pop up on the radar and be classified as democracies, even though many scholars would be able to point out intuitively there is something dodgy about them. Thanks to L\&W, the concept has been integrated fully in the field of comparative politics and regime theories. This 
does not mean however, that all researchers decided to frame the category of hybrid regimes in the same way as its creators. Examples are manifold and as this paper does only describe examples for illustrative purposes, only the approach of A. Schedler will be brought up here.

Schedler's concept of 'Electoral authoritarianism' is much broader than Levitsky \& Way's 'Competitive authoritarianism'. For Schedler, the presence of free elections and especially the opening of civil society, which allows organized dissidence in the form of multiparty competition, is already meaningful enough to separate these regimes from their closed authoritarian counterparts (Schedler, 2006, p. 5-6). L\&W on the other hand, distinguish between competitive and hegemonic regimes. The former has meaningful competition and even while the playing field is not fair, the outcome of elections is uncertain. Elites in these regimes do 'sweat' when the votes are being counted. In the latter, democratic institutions only exist on paper, but elections are so "marred by repression, candidate restrictions, and/or fraud that there is no uncertainty about their outcome." (Levitksy, Way, 2010, p. 6-7). Schedler's concept of electoral authoritarianism covers both concepts (Schedler, 2006). In both cases, and many others not discussed in this paper, the authors bring up arguments to treat these regimes as a separate type, even when its boundaries are defined differently. Their individual arguments are cases in point to defend the existence of a group of trichotomous categories.

A very clear overview of these two concepts (and others) has been presented in the map of the current field of regime types by L. Gilbert and P. Mohseni. Figure 1. shows how Schedler's concept covers both Levitsky \& Way's 'competitive authoritarian type,' but also includes regimes marred by such uncompetitive elections, whose outcomes are not uncertain (hegemonic electoral authoritarian). While Gilbert \& Mohseni's efforts to map these different definitions to achieve a better understanding of the murky conceptual waters that ebb and flood between democracy and full autocracy, can only be praised, the author of this article argues against their recommendation to re-define 'electoral regimes'. Gilbert \& Mohseni argue that only those regime types that hold competitive multiparty elections possess enough particular characteristics to exhibit different behavior, and in return only those regimes merit the title 'electoral regimes' or hybrid regimes. As their need for conceptual clarification is understandable, this paper argues that all trichotomous classifications have their merits, depending on the research they focus on.

The family of trichotomous typologies focuses on how the introduction or presence of elections affects regimes and their behavior. Most of them perform research on the bulk of these hybrid regimes and their prospects for democratization. There exists a certain level of consent in the literature that this regime type is the most common stepping stone to democracy, especially the competitive one identified by L\&W. ${ }^{5}$ To stick with this example and the one of Schedler; it is useful to have research available that focuses on the same broad phenomenon (the level of political competition in political regimes) by using different typologies. While L\&W focus on the influence of 'uncertainty' of electoral outcomes and its effects on regime behavior, Schedler analyzes the broader impact of the presence of elections in political regimes. Dependent on the research, all the authors

${ }^{5}$ Hadenius \& Teorell provide quantitative proof of this thesis (Hadenius, Teorell, 2007). 
should use an existing typology that suits their unit of analysis best or develop one if the former is lacking.

\begin{tabular}{|c|c|c|c|c|}
\hline $\begin{array}{c}\text { Closed } \\
\text { Authoritarian }\end{array}$ & $\begin{array}{c}\text { Hegemonic } \\
\text { electoral } \\
\text { authoritarian }\end{array}$ & $\begin{array}{c}\text { Competitive } \\
\text { authoritarian } \\
\text { (Levitsky \& Way) }\end{array}$ & $\begin{array}{c}\text { Electoral } \\
\text { democracy }\end{array}$ & $\begin{array}{c}\text { Liberal } \\
\text { democracy }\end{array}$ \\
\hline
\end{tabular}

Electoral authoritarianism (Schedler)
Adapted conceptual map of the current field of regime types. (Source: Gilbert, Mohseni, 2011, p. 275)

\section{Polychotomous measures}

The last groups of typologies are those that use a pluralistic approach to classify political regimes. Their categories tend to be more complicated, their datasets less robust and less universal in scale, and in general they favor the study of autocratic regimes. It is difficult and time consuming to create large datasets based on these typologies, mostly because of lack of data on regimes prior to the Second World War. Among all typologies their classification criteria are most often disputed and usually designed for specific research ends.

Despite their different analytical lenses, these typologies usually aim to provide explanations on all four dimensions. They assess a regime's character, based on its formal and informal rules, identify different nexuses of power that interact with each other (a royal dynasty, the army, the dominating party, opposition groups), and explain various forms of behavior based on these internal dynamics. They frequently present meaningful classifications that allow them to explain differences on the horizontal and vertical dimension.

For illustrative purposes, this paper will briefly compare the typology devised by Geddes et al. with the one of Hadenius \& Teorell. As the latter was first heavily inspired by the former, and since afterwards Geddes updated her model to include monarchies like in Hadenius \& Teorell; both models are similar and mostly differ on one dimension: The 'who rules?' question. The research of Geddes et al. focuses on the behavior and lifespan of the executive in different autocracies. Therefore, their main question is: Who executes power? From what group are the political leaders? Hadenius \& Teorell seek a similar answer, but pose the question differently in order to assess, which regimes should democratize easier: What group possesses the nexus of power to rule the state? Who pulls the strings?

Once more, two slightly different typologies, each with its own dataset led to roughly similar outcomes. Both are very useful for their own unit of analysis, but are not interchangeable. Geddes et al. for instance, do not take into account the presence of elections and therefore are not able to analyze its impact on democratization or regime behavior. Hadenius \& Teorell on the other hand, do not focus on leadership and their typology cannot attribute any relevance of personalist rule to regime theory. 
Regime typologies and their merits

\begin{tabular}{|c|c|c|c|c|}
\hline Family & Level & Main question & Main focus* & Main explanations \\
\hline \multirow[t]{3}{*}{ Categorical } & Dichotomous & $\begin{array}{l}\text { How can we classify the } \\
\text { behavior of states? }\end{array}$ & Character & $\begin{array}{l}\text { - Explaining (foreign) policy or } \\
\text { performance by breaking open } \\
\text { the black box of the state. }\end{array}$ \\
\hline & Trichotomous & $\begin{array}{l}\text { How do elections affect } \\
\text { regimes and their be- } \\
\text { havior? }\end{array}$ & $\begin{array}{l}\text { Character, } \\
\text { Horizontal } \\
\text { Vertical } \\
\end{array}$ & $\begin{array}{l}\text { - Democratization of states and } \\
\text { political systems from within. }\end{array}$ \\
\hline & Polychotomous & $\begin{array}{l}\text { How does the internal } \\
\text { constellation affect regi- } \\
\text { mes and their behavior? }\end{array}$ & $\begin{array}{l}\text { Character } \\
\text { Who rules? } \\
\text { Horizontal } \\
\text { Vertical }\end{array}$ & $\begin{array}{l}\text { - Duration of regimes. } \\
\text { - Impact of leadership. } \\
\text { - Tolerance vis-ŕr-vis opposition } \\
\text { and dissent. } \\
\text { - Resistance to democratization } \\
\text { by external and internal actors. }\end{array}$ \\
\hline Continuous & - & $\begin{array}{l}\text { What is the level of fre- } \\
\text { edom? }\end{array}$ & $\begin{array}{l}\text { Horizontal } \\
\text { Vertical }\end{array}$ & $\begin{array}{l}\text { - Democratization of countries } \\
\text { over time. (Alarm bell) } \\
\text { - Human rights record of regimes }\end{array}$ \\
\hline
\end{tabular}

*Main focus according to Skaaning's 4 defining characteristics of regimes:

- Character of the regime - The institutionalized set of fundamental formal and informal rules identifying the political power holders.

- Who rules? - Regulation of the appointments to the main political posts.

- Vertical limitations - Extension and character of civil liberties.

- Horizontal limitations - Extension and character of division of powers.

Source: Skaaning, 2006; Boix, Miller, 2012.

Table 2. gives an overview of all forms of typologies, their main focus according to Skaaning's definition and their usual field of explanation. As the table above shows, every family of typologies highlights some dimensions while ignoring others. The author argues that instead of selecting only one typology and accepting its limits, researches could focus on the omitted aspects and find a typology that is complementary to address the issue in detail.

Moreover, Skaaning's four dimensions can be extrapolated into six research areas that together encompass the focus of regime theory and democratization studies. As figure 2 below shows: Dichotomous typologies (A) address the general character of regimes albeit in a zero-sum way and provide

Figure 2. A map of regime typologies

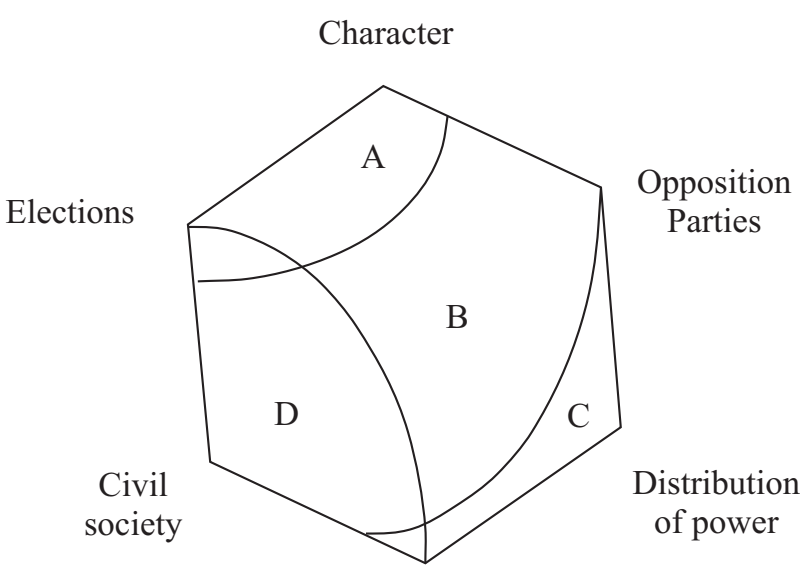

Freedom 
some analytical tools on how to assess elections. Trichotomous approaches (B) cover a broader research area by also focusing on the nature of opposition parties and the level playing field (civil society).

Continuous measures (D) provide great insight into the level playing field (elections, civil society) and give detailed ranking on the various levels of freedom present in a given regime. They, however, lack the categorical qualities to set an exact threshold and make a clear distinction between democracy and authoritarianism. Finally, polychotomous typologies (C) cover the whole spectrum, but do concentrate on the distribution of power in particular, which regulates the relations of regimes vis-à-vis other elements of the map. As they offer such a broad analytical framework, general explanations become difficult as scholars cannot assess which elements (opposition parties, elections, civil society, etc.) are the most salient for specific outcomes, besides the distribution of power.

The author hopes that by mapping regime typologies, he could provide a modest contribution to aid scholars of regime theories in reflecting on the limits of their chosen framework and for selecting typologies according to their research area.

\section{Bibliography}

Alvarez M., Cheibub J. A., Limongi F., Przeworski A. (1996), Classifying Political Regimes, "Studies in Comparative International Development", vol. 31, no. 2, pp. 3-36.

Boix C., Miller M., Rosato S. (2012), A Complete Data Set of Political Regimes 1800-2007, "Comparative Political Studies", vol. 20, no. 10, pp. 1-32.

Boogaards M. (2010), Measures of Democratization: From Degree to Type to War, "Political Research Quarterly", vol. 63, no. 2, pp. 475-488.

Chan S. (2004), Liberalism, Democracy and Development, Cambridge University Press, Cambridge.

Cheibub J. A., Gandhi J., Vreeland J. R. (2009), Democracy and dictatorship revisited, "Public Choice", DOI 10.1007/s11127-009-9491-2.

Cutright Ph. (1963), National political development: Measurement and analysis, "American Sociological Review", vol. 28, no. 2, pp. 253-264.

Dunn J. (2005), Democracy: A history, Atlantic books, New York.

Ekman J. (2009), Political Participation and Regime Stability: A Framework for Analyzing Hybrid Regimes, "International Political Science Review", vol. 30, no. 1, pp. 7-31.

Elman C. (2005), Explanatory Typologies in Qualitative Studies of International Politics, "International Organization", vol. 59, no. 2, pp. 293-326, DOI 10.1007/s12116-011-9088-x.

Fearon J. D., Laitin D. D. (2003), Ethnicity, Insurgency, and Civil War, "The American Political Science Review", vol. 97, no. 1, pp. 75-90.

Fishman R. M. (1990), Rethinking State and Regime: Southern Europe's Transition to Democracy, "World Politics", vol. 42, no. 3, pp. 422-440.

Frantz E., Ezrow N. (2011), The Politics of Dictatorship: Institutions and Outcomes in Authoritarian Regimes, Lynne Rienner, London.

Gasiorowski M. J. (1996), An overview of the political regime change dataset, "Comparative Political Studies", vol. 29, no. 4, pp. 469-483.

Geddes B., Wright J., Frantz E. (2012), Autocratic Regimes, Research supported by NSF-BCS \#0904463 and NSF-BCS \#0904478.

Geddes B., Wright J., Frantz E. (2013) New Data on Autocratic Breakdown and Regime Transitions, Research supported by the National Science Foundation, BCS-0904478 and BCS-090463. 
Gilbert L., Mohseni P. (2011), Beyond Authoritarianism: The Conceptualization of Hybrid Regimes, "St Comp Int Dev", vol. 46, pp. 270-297.

Hadenius A., Teorell J. (2007), Pathways from authoritarianism, "Journal of Democracy", vol. 18, no. 1 , pp. 143-157.

Hegre H., Ellingsen T., Gates S., Gleditsch N. P. (2001), Toward a Democratic Civil Peace? Democracy, Political Change, and Civil War, 1816-1992, "The American Political Science Review", vol. 95, no. 1, pp. 33-48.

Kailitz S. (2013), Classifying political regimes revisited: legitimation and durability, "Democratization", vol. 20, no. 1, pp. 39-60.

Levitsky S., Way L. A. (2010), Competitive Authoritarianism: Hybrid regimes after the Cold War, Cambridge University Press, Cambridge.

Linz J. J. (2000), Totalitarian and authoritarian regimes, Lynne Rienner Publishers, London.

Linz J. J., Stepan A. (1996), Problems of democratic transition and consolidation: Southern Europe, South America, and post-communist Europe, Johns Hopkins University Press, Baltimore.

Mainwaring S., Brinks D., Pérez-Liñán A. (2007), Classifying political regimes in Latin America, 1945-2004, in: Regimes and democracy in Latin America: Theories and methods, ed. G. L. Munck, Oxford, p. 123-160.

Marshall M. G., Gurr T. R. (2005), Polity IV Index Project, http://www.systemicpeace.org/polity/polity4.htm.

Regan P. M., Bell S. R. (2010), Changing Lanes of Stuck in the Middle: Why Are Anocracies More Prone to Civil Wars?, "Political Research Quarterly", vol. 63, no. 4, pp. 747-759.

Reich G. (2002), Categorizing Political Regimes: New Data for Old Problems, "Democratization", vol. 9 , no. 4 , pp. 1-24.

Russet B. (2011), Hegemony and Democracy, "Security and Governance series”, edited by F. Adamson et al., Routledge, London.

Sartori G. (1987), The theory of democracy revisited, Chatham House, Chatham, NJ.

Schedler A. (2006), Electoral Authoritarianism: The Dynamics of Unfree Competition, Lynne Rienner Publishers, London.

Skaaning S. (2006), Political Regimes and Their Changes: A Conceptual Framework, "CDDRL Working Papers", Freeman Spogli Institute for International Studies, Stanford University, no. 55 .

Van den Bosch J. (2013), Political Regime Theory: Identifying and Defining Three Archetypes, "Copernicus Journal of Political Studies", vol. 2.

Vreeland J. R. (2008), The Effect of Political Regime on Civil War: Unpacking Anocracy, "The Journal of Conflict Resolution”, vol. 52, no. 3, pp. 401-425.

\section{Odwzorowanie polityczne typologii reżimu}

\section{Streszczenie}

W dziedzinie badań poświęconych teorii reżimów występuje znaczne zróżnicowanie podejść oraz typologii stawiających sobie za cel wyjaśnienie dynamicznie zmieniającej się rzeczywistości. Zamierzeniem autora niniejszego artykułu było zaproponowanie własnej typologii obejmującej istniejące już typologie, co z kolei posłużyło do opisania i analizy wartości badawczej tychże typologii oraz powiązanych z nimi baz danych. Pozwoliło to na wskazanie relacji między opisanymi typologiami i określenie ich miejsca we właściwych im polach badawczych. Celem tego działania jest dokonanie refleksji nad 
stosowalnością poszczególnych typologii, pokazanie ich ograniczeń oraz ułatwienie wyboru między nimi badaczom zajmującym się analizą procesów demokratycznych oraz teorią reżimów politycznych, z zastosowaniem zarówno jakościowych, jak i ilościowych metod badawczych.

Słowa kluczowe: reżimy polityczne, typologie, pomiary demokratyzacji, metody badawcze 